\section{Organic farmers sue GMO producers}

$\mathrm{O}_{\mathrm{n}}^{\mathrm{n}}$ January 10, the Saskatchewan Organic Directorate (SOD; Saskatoon, Canada), an umbrella organization representing about 1,000 certified organic farmers, initiated a class action lawsuit against agbiotech companies Monsanto Canada (Mississauga, Canada) and Aventis Cropscience Canada (Regina, Canada), seeking compensatory damages for revenues lost through contamination of organic crops with the companies' GM herbicide-tolerant canola. In an effort to protect their most important organic crop, they are also seeking an injunction to halt ongoing field trials of Monsanto's Roundup Ready wheat. If found liable for damage to the environment, developers of GM technology worldwide could face losing millions of dollars in similar claims filed by farmers of organic or conventional crops.

GMOs are prohibited substances, according to the Canadian General Standards Board's Organic Agriculture Standards, in line with the International Federation of Organic Agriculture Movements (Tholey-Theley, Germany), which operates a zero tolerance policy. The plaintiffs say that GM canola has widely proliferated since its introduction in 1995 and has been found growing on unintended land. "The contamination has reached a level such that very few, if any, pedigreed seed growers in Saskatchewan will warrant their canola seed to be GMO-free," the plaintiffs state in their claim. "The crop, as an important tool in the crop rotations of organic farmers, and as an organic grain commodity, has been lost to certified organic farmers."

Arnold Taylor, president of the SOD, says contamination has destroyed not only domestic but also international sales, which provide the bulk of organic revenues. Susan Mudry, organic statistician for the Canadian Grain Commission (Winnipeg), notes that preliminary estimates of canola (organic plus conventional) exported to Eastern Europe are zero for August 2000-July 2001, down from over 500 metric tons the prior year.

Canadian farmers are worried that their estimated C\$28 (\$17.5) million organic wheat industry, which accounts for about half of the industry's revenue, will be damaged in the same way should GM wheat be introduced. "Wheat is the most important grain grown by certified organic grain growers, and is their largest export," state the plaintiffs. "If GM wheat is released into the Saskatchewan environment on such an unconfined and commercial basis, organic grain farmers will suffer irreparable harm."

The plaintiffs say the blame lies with

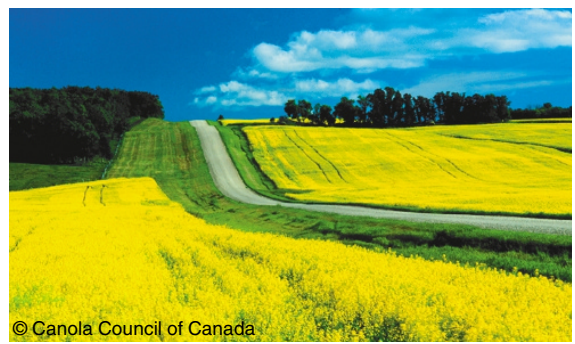

Organic farmers claim they have lost revenues through contamination of their crops with GM canola developed by Monsanto and Aventis.

Monsanto and Aventis, as opposed to the farmers, because, contrary to federal guidelines, they did not warn growers about the potential harm to neighboring crops or advise them of farming practices and safeguardssuch as buffer zones and proper securing of vehicles - to limit the spread of GM canola through accidental cross-pollination or seed dispersal. Monsanto spokesperson Trish Jordan argues that there are only guidelines, not laws, governing these things. She says Monsanto is not at fault in any case because it does not sell seeds directly to farmers, but to seed companies that act as middlemen. Moreover, Jordan points out that it was the government that approved the transgenic crops after assessing human and environmental safety.

However, lawyers say the plaintiffs have a strong case and, to be awarded damages, need only demonstrate that defendants caused a loss of organic certification, loss of access to domestic or international organic markets, or loss of business contracts. Taylor expects the organic farmers to receive damages in the order of millions of dollars, and suggests that agbiotech firms could lose a lot more should conventional farmers-who grow about 3.5 million acres of canola in Saskatchewan alone-subsequently file similar suits.

The plaintiffs assert damages under six claims, four of which are common law civil wrong claims: trespass (when the defendant intentionally causes damage to the plaintiff's land), nuisance (when the defendant inhibits the plaintiff's enjoyment of their land), strict liability (when the defendant has caused damage by "abnormally dangerous" behavior), and negligence (when the plaintiff is injured because the defendant has failed to perform a duty of care). David Moeller, attorney for Farmers' Legal Action Group (St. Paul, MN), a non-profit law center that represents farmers, says the companies may be found guilty of trespass or nuisance, if the plaintiffs can show exactly from which fields the contaminant GM pollen or seeds came. And while there is no evidence that GM crops are dangerous to human health or the environment, the companies could be found guilty of strict liability for damage to organic farmers' wallets. Moeller points to the similarity between this case and that of Langan $v$. Valicopters (1977), a Washington state supreme court case that awarded damages under strict liability to an organic farmer whose crops were inadvertently sprayed with chemical pesticides by a neighboring farmer.

As for negligence, Terry Zakreski, the SOD's lawyer in Saskatchewan, believes the firms could be found liable thanks to the result of the high-profile case, Schmeiser v. Monsanto Canada, Inc. and Monsanto, in which a Saskatchewan canola farmer was found to have infringed upon Monsanto's Roundup Ready patent when GM canola was found in abundance on his land without having been licensed from the firm (Nat. Biotechnol. 19, 396, 2001). "If farmers are responsible to Monsanto because this strain belongs to Monsanto wherever it ends up," ascertains Zakreski, "then the flipside of that is Monsanto is responsible to farmers if it's causing any damage. So they can't claim that they're not ... responsible for it if they're suing farmers that have it on their land."

The other two claims fall under provincial environmental laws. In one, the plaintiffs claim that the transgenes present in the companies' GM canola are "pollutants" under The Environmental Management Protection Act, and as such the firms are responsible for harm to agricultural uses of the environment caused by them. The plaintiffs also say that the firms failed to conduct environmental impact studies that are required under the Environmental Assessment Act to approve GM canola in the province, regardless of national approval of the products by the Canadian Food Inspection Agency.

Meanwhile, biotechnology industry representatives say the organic lobby has brought this situation on itself by insisting on the exclusion of transgenic crops from organic certification, despite the fact that rigorous testing has shown that these crops are at least as safe as conventional or organic varieties. In addition, Val Giddings, vice president of Food and Agriculture at the US Biotechnology Industry Organization (Washington, DC), points out that "The biotech companies [Monsanto and Aventis] are not responsible for the failure of foreign governments to honor their obligations under the WTO," referring to the World Trade Organization's (Geneva) policy that member countries cannot legally refuse imported crops unless they are scientifically proven to be hazardous.

Aaron Bouchie, New York 